\title{
Personal and Collective Efficacy Beliefs Scales to Educators: Evidences of Validity
}

\author{
Daniela Couto Guerreiro Casanova - Universidade Estadual de Campinas, Campinas, Brasil \\ Roberta Gurgel Azzi - Universidade Estadual de Campinas, Campinas, Brasil
}

\begin{abstract}
This paper presents the Teacher Self-efficacy Scale, short version, and the School Collective Beliefs Scale adaptation and search of validities evidences process. After the semantic-cultural adaptation process, this study was composed by 380 educators from the public educational system in the state of São Paulo. The teacher self-efficacy scale, composed by 12 items, was organized into three factors. The School Collective Efficacy scale, composed by 12 items, was structured into two factors. Such adaptations, through the exploratory factor analysis yielded similar factor structure to the original scales, showed good evidence for variance explained, and internal consistency. Convergent validity was verified by the significant correlation between self-efficacy and collective efficacy. Criteria validity was verified through significant correlations between these beliefs and school performance. It is suggested to increase the sample size to confirm these results.
\end{abstract}

Keywords: self-efficacy, collective efficacy, teachers

Escalas de Crenças de Eficácia Pessoal e Coletiva para Educadores: Evidências de Validade

\begin{abstract}
Resumo
Este artigo apresenta o processo de adaptação e de busca de evidências de validade da escala de Autoeficácia Docente, versão curta, e da escala de Crença Coletiva Escolar. Após o processo de adaptação semântico-cultural, este estudo contou com a participação de 380 educadores da rede estadual de São Paulo. A escala de Autoeficácia Docente, composta por 12 itens, organizou-se em três fatores. A escala de School Collective Efficacy, composta por 12 itens, estruturou-se em dois fatores. Tais adaptações, por meio da análise fatorial exploratória, mantiveram as estruturas fatoriais semelhantes às escalas originais e demonstraram boas evidências relativas à explicação da variância e à consistência interna. A validade convergente foi verificada por meio da correlação significativa entre a autoeficácia e a eficácia coletiva. A validade de critério foi constatada por meio das correlações significativas entre essas crenças e o desempenho escolar. Sugere-se ampliar a amostra para confirmar tais resultados.

Palavras-chave: autoeficácia, eficácia coletiva, professores
\end{abstract}

Escalas de Creencias de Eficacia Personal y Colectiva para Educadores: Evidencias de Validez

\begin{abstract}
Resumen
Este artículo presenta el proceso de adaptación y la búsqueda de evidencias de validez de la Escala de Autoeficacia Docente, versión reducida, y de la escala de Creencia Colectiva Escolar. Después del proceso de adaptación semántico y cultural, el estudio contó con la participación de 380 profesores del sistema público de educación de São Paulo. La escala de Creencia Colectiva Escolar, compuesta por 12 ítems, se estructuró en dos factores. Estas adaptaciones por medio del análisis factorial exploratorio, mantuvieron las estructuras factoriales semejantes a las escalas originales y mostraron buenas evidencias relativas a la explicación de la variabilidad y consistencia interna. La validez convergente fue verificada por medio de la correlación significativa entre la autoeficacia y la eficacia colectiva. La validez de criterio se constató por medio de las correlaciones significativas entre esas creencias y el rendimiento escolar. Se sugiere ampliar la muestra para confirmar tales resultados.

Palabras clave: autoeficacia, eficacia colectiva, profesores
\end{abstract}

This article aims to present the process of adaptation and search for evidence of validity of the Teacher Self-Efficacy Scale, short version (Tschamannen-Moran \& Woolfook-Hoy, 2001), and the School Collective Efficacy Scale (Tschannen-Moran \& Barr, 2004). These scales were selected because they presented content based on the Social Cognitive Theory, which is the theoretical ground of the construct that they aim to measure, as well as good evidence of validity in international researches. Furthermore, they have been pointed out as good instruments to identify the perception of personal and collective efficacy of teachers (Klassen, Tze, Betts \& Gordon, 2011).
Teacher self-efficacy and collective teacher efficacy are two different constructs (Bandura, 1993; 1997; Skaalvik \& Skaalvik, 2007). However, they have some similar characteristics. The characteristics inherent to self-efficacy beliefs are understood as the perceived capability to perform a determined action by a person in a determined environment, and the characteristics inherent to collective beliefs are related to the perception of a group of people regarding their capability of execution in a determined environment.

The school units are good examples of environments in which it is possible to analyze the coexistence of personal and collective beliefs permeating everyday 
life. This is because the actions of teachers and school principals are individual actions when each one has to carry out his or her own tasks, and are collective actions when people have to take actions in order to achieve common objectives, so that there is an interdependence of the actions taken to the school context (Bandura, 1993). As already mentioned, the two beliefs are independent, but studies show correlation between them (Bandura, 1993).

Teacher self-efficacy beliefs are defined as "teacher's perceptions about their own capabilities to achieve desired results of engagement and student learning, even among those who may be difficult or unmotivated" (Tschannen-Moran \& Woolfolk-Hoy, 2001, p. 783). Studies have associated the perception of teacher self-efficacy to the most successful instructional actions, as well as classroom management based on a more humanistic approach, including aspects that favor learning, motivation, autonomy, and student performance (Klassen, Usher \& Bong, 2010). School collective efficacy beliefs are defined as the teachers' perception about the capability of the group of teachers to organize and execute the courses of action required to promote learning and stimulate the academic self-efficacy and self-regulation of the students (Bandura, 1997). Researches have highlighted the mediating role of the school collective efficacy belief to the performance and motivation of students, as well as to the motivation of teachers (Goddard, Hoy \& Hoy, 2000; Guerreiro-Casanova, 2013; Hoy, 2012; Klassen et al., 2010; Skaalvik \& Skaalvik, 2007; Tschannen-Moran \& Barr, 2004). Both beliefs, at the professional level, contribute for the teachers to feel more satisfied and fulfilled with their work, avoiding burnout and extending the length of time in the teaching profession (Azzi \& Polydoro, 2010; Bandura, 1997; Goddard et al., 2000; Klassen et al., 2010; Skaalvik \& Skaalvik, 2007; Tschannen-Moran \& Woolfolk-Hoy, 2001).

The associations between teacher self-efficacy beliefs and the school collective efficacy beliefs, with actions included as positive for the realization of the teaching activity (for instance, good management of the classroom, teacher and student motivation, among others), are the result of the influences of these beliefs in the cognitive, affective, and motivational selective processes that underlie human actions. Through these processes, these beliefs can affect the instructional and disciplinary actions taken by teachers and school principals, both in individual and collective actions conducted by the group of teachers and principals (Bandura, 1993; 1997).

Both beliefs are understood as dynamic, because the perception of the intensity relative to them may fluctuate. This oscillation can occur according to the interpretation that the individual or the collective has on the information from their own experiences, of the vicarious experiences, the social persuasion received, and their own physical and emotional state. These beliefs are built over the teaching career, through the interpretation of information that the school context provides the teachers who act on it (Bandura, 1997; 2008).

Beliefs of self-efficacy may vary according to three dimensions: strength, level, and generality. The strength dimension is related to the intensity of the conviction towards a given domain of action. Low self-efficacy beliefs may be easily deconstructed by failure situations, while more intense efficacy perceptions help dealing with crises and overcoming failures (Bandura, 1997; Polydoro, Azzi \& Vieira, 2010). For instance, a teacher with strong self-efficacy beliefs for dealing with students that are considered difficult, even when faced with difficulties in dealing with a particular student or a particular environment, will not let this failure diminish their belief, but rather, will attempt to reflect on the situation and find new ways to solve it.

The level dimension refers to the extent of the belief towards the diversity of challenges and/or difficulties that make up a particular field of action (Bandura, 1997; Polydoro, Azzi \& Vieira, 2010). For instance, a teacher can perceive himself as self-effective to teach high school in a class with 30 students, but not in a class with 50 students.

The generality dimension refers to the broad combination of aspects that make up an action domain. The generality of the domain to be investigated should be defined by the researcher, according to the research objectives, and it is important to identify the multiple dimensions that comprise it (Bandura, 2006). In the teaching field, it is possible to specify the generality of self-efficacy beliefs to teach, considering the instructional aspects and the engagement of students that occur within the classroom, or it is possible to extend the generality of the teacher self-efficacy belief, considering also the aspects related to the bureaucratic actions that are part of the profession (Bandura, 1997; Polydoro, Azzi \& Vieira, 2010), for instance.

To measure teacher self-efficacy and collective efficacy beliefs is a complex task, as they are dynamic 
and susceptible to environmental influences (Bandura, 2006). It is not possible to identify whether a teacher or a school is effective or not. It is possible, however, to identify perceptions of these beliefs at a given moment and under specific conditions (Tschannen-Moran \& Johson, 2011). Assessment scales have been one of the most used instruments to perform the identification of these beliefs (Klassen, Tze, Betts \& Gordon, 2011), and it's necessary to ensure that such instruments are reliable and demonstrates minimum criteria of reliability and validity evidence (Anastasi \& Urbina, 2000; Freire \& Almeida, 2001) also for the Brazilian population (Santos, 2011). It is recommended that these scales: (1) are composed of items written in the present tense, to guide the respondent to think about their capability to carry out such activity at that moment and not about the intention to perform it; (2) have possibilities of responses in a Likert format 1 to 10 , to broaden sensitivity of the scales regarding the strength of the measured perception; (3) have items in sufficient quantity to include several actions and/or tasks within the area to be investigated, so that the scale can facilitate the achievement of a vision of the generality of the belief; (4) have items that present different degrees of intensity within the investigated area; and (5) are specific to a domain of action, so that the scale used to measure the teacher self-efficacy belief is different than the used to measure the perception of efficacy to teach chemistry or to act as a school manager, for instance, due to the nature of their attributions (Bandura, 2006; Polydoro et al., 2010).

Specifically for the collective efficacy belief, according to Bandura (1997, 2008), there are three methods to measure it: (1) adding perceptions written with a focus on the individual capacity of each member of the group for the roles that they play in such group; (2) adding the collective efficacy perceptions, so that the questions are already written with a focus on the group's capability to carry out the tasks incumbent on it; (3) by consensus, opportunity in which group members meet and discuss the perception of collective efficacy of the group, until they reach a consensus. The second method has been more recommended to capture the perceptions of collective efficacy (Bandura, 1997; 2008), as it is possible to obtain the perception on the collective capability and not on the individual capability of members of the group, as in the first method, and it may avoid persuasions under the third method, via consensus.
In Brazil, at the beginning of this research, in 2010, two adaptations of rating scales for use in the teaching field were located through searches performed in Capes, Pepsic, and SciELO Brasil databases. Bzuneck and Guimarães (2003) adapted the teacher self-efficacy scale of Woolfolk and Hoy (1990), consisting of 20 items organized into two factors: sense of personal efficacy $(\alpha=0.73)$ and sense of efficacy for teaching $(\alpha$ $=0.70$ ), which explained $30.86 \%$ of the variance. Polydoro, Winterstein, Azzi, Carmo, and Venditti Junior (2004) adapted the teacher self-efficacy scale (Tschamannen-Moran \& Woolfolk-Hoy, 1998 - long version) specifically for physical education teachers. This adaption is composed of 24 items $(\alpha=0.93)$ organized in two dimensions: efficacy in the intentionality of the teaching action $(\alpha=0.91)$ and efficacy in class management $(\alpha=0.86)$. Although this Brazilian adaption kept the 24 original items, the factor analysis found was different than that verified in the US original scale, in which there were three factors named efficacy on the instructional strategies, efficacy on classroom management, and efficacy in engaging the student.

In a literature review conducted through Eric and Scopus databases, also in 2010, it was identified that international researches used the short version (with 12 items) of the teacher self-efficacy scale (Tschamannen-Moran \& Woolfolk-Hoy, 1998). This version has shown good evidence of validity, presenting conditions of measuring the teacher self-efficacy construct in several cultures (Klassen et al., 2009; Klassen et al., 2011), besides enabling lower application time, an important aspect, especially when considering the use of this scale along with other instruments. Therefore, the short version turned out to be a unique option for a process of adaption in Brazil, which will be presented here.

As for the collective teacher efficacy, the Brazilian Inventory of Collective Teacher Efficacy - IBECP (Bzuneck, Boruchovitch \& Rufini, 2014) was recently published. This scale was developed considering the national educational performance context. It consists of 22 items organized in a unifactor structure and showed adequate evidence of construct validity.

It's noteworthy that in 2010, when the research with the collective efficacy scale was initiated, there was no public information about any study conducted with the school collective efficacy scale in Brazil. This finding was obtained through searches performed in Capes, Pepsic, and Scielo databases in 2010 and highlighted the need to create and/or adapt scales aimed at identifying the perceived school collective 
efficacy (Dantas, Guerreiro-Casanova \& Azzi, 2012), which could help to understand how a school comprehends its collective capacity. Therefore, this article aims to present the process of adaption and search for evidence of validity related to the content, the convergence patterns, and to a previously established criterion for both scales presented.

\section{Method}

\section{Participants}

The study to search for evidence included 380 professionals: 8 principals, 8 vice-principals, 25 pedagogical coordinators, and 339 primary and secondary school teachers. These participants came from 17 public state schools of elementary and secondary education; selected by convenience, from the municipalities of Campinas, Pedreira, São Bernardo do Campo, and São Caetano do Sul, located in the state of São Paulo.

This sample consisted of 277 female and 93 male, with a mean age of 43.33 years $(S D=10$; with age ranging from 22 to 67 years). Regarding the training, this sample had 23 educators who were graduated in pedagogy, 209 from various courses, 108 were postgraduated, 21 held master's titles, and 6, titles of PhD. This sample had, on average, 34.40 working hours a week $(S D=11.35)$, and most of them $(n=247)$ worked only in the school investigated; 72 worked in the investigated school, and in another public school, 34 in the investigated school and another private school, and 17 worked in the investigated school and in other public and private schools.

It is important to emphasize that the Teacher SelfEfficacy Scale was answered only by teachers since it is focused on tasks related to teaching and not to school management. Also, only the scales fully responded by the participants were considered. These aspects may explain possible differences in the number of respondents - $\mathrm{n}$ - throughout this text.

\section{Instruments}

The instruments used for data collection are described below:

Questionnaire about participants: This questionnaire was developed by the researchers to obtain information on personal characteristics, characteristics about the teaching activity and about the professional context of participants. It was a questionnaire with objective questions regarding age, gender, time of teaching, type of professional training, type of employment contract, amount of working hours, educational background, among other personal and professional characteristics.

Teacher Self-Efficacy Scale - Short Version (Tschannen-Moran \& Woolfolk-Hoy, 2001): this scale was used to identify the perception of teachers in relation to their teacher self-efficacy beliefs. The original version of the scale (Tschannen-Moran \& WoolfolkHoy, 2001) may be found in the long format, with 24 items, and short, with 12 items, with possible answers in the Likert-like format of 9 points. The scale in short format is organized in three factors: (1) efficacy in student engagement, with 4 items, internal consistency of 0.81 , and explained variance of $69.10 \%$; (2) efficacy in instructional strategies, with 4 items, internal consistency of 0.86 and explained variance of $47.30 \%$; and (3) efficacy in the classroom management, with 4 items, internal consistency of 0.86 , and explained variance of $59.89 \%$. In total, this scale shows internal consistency of 0.90 and explained variance of $65 \%$. This scale may be used by its factors, or in total, as suggested by the authors (Tschannen-Moran \& Woolfolk-Hoy, 2001). However, the use of factors increases the capacity of understanding teacher self-efficacy, since this is a multidimensional construct (Bandura, 2006; Tschannen-Moran \& Woolfolk-Hoy, 2001).

A cross-cultural study conducted in five countries (Canada, Cyprus, Korea, Singapore and United States), with primary and secondary school teachers, verified adequate evidence of validity for this scale (short form with 12 items) in different contexts, showing invariability of measures and adequate internal consistency (Canada, $\alpha=0.89$; Cyprus, $\alpha=0.93$; Korea, $\alpha=0.92$; Singapore, $\alpha=0.94$ and United States, $\alpha=0.87)$. In the five countries investigated, the scale kept the original organization, with three factors and 12 items in Likertlike format of 9 points (Klassen et al., 2009). This scale is considered a good instrument to measure teacher self-efficacy, as, besides the adequate psychometric data, it presents congruence with the theoretic specifications of the self-efficacy construct, being related to a specific context, and focusing on the perception of one's own capability to handle a specific task (Klassen et al., 2011). Given these favorable results, it was decided to adapt this scale to the Brazilian context.

School Collective Belief Scale (TschannenMoran \& Barr, 2004): the original version of this scale was drawn from the Teacher Self-Efficacy Scale (Tschannen-Moran \& Woolfolk-Hoy, 2001), named Collective Teacher Belief Scale, as it's designed to 
verify the perception of collective teacher efficacy. This scale follows the guidelines by Bandura $(1986,1997)$ to measure the perception of collective efficacy and was measured according to the second method proposed by Bandura (1986; 1997; 2008), in which all items use the present tense and are intended to identify the perception of collective efficacy, with emphasis on the searched group's collective capability, in this case, educators who work in the same school unit.

This scale consists of 12 items, with possible answers in a 9-point Likert-like scale, ranging from none at all to a great deal. It is organized on two factors: (1) instructional strategies, with internal consistency of 0.96; and (2) students discipline, with internal consistency of 0.94 . The internal consistency of the total scale is 0.97 . Information on the internal consistency show that the Teacher Collective Belief scale seems to be adequate for the measurement of the perception of collective efficacy (other information, such as the scale's explained variance were not disclosed). In addition, this scale shows evidence for the validity construct that is intended to measure, being congruent with theoretical foundation of collective efficacy (Klassen et al., 2011).

Performance Index: annually, the Board of Education of the state of São Paulo organizes a school performance evaluation, named Sistema de Avaliação de Rendimento Escolar do Estado de São Paulo - SARESP, considering the performance shown by students attending the $3 \mathrm{rd}, 5 \mathrm{th}, 7 \mathrm{th}$, and 9th years of elementary school and the 3rd year of high school in the disciplines Portuguese, Mathematics, Geography, and History. The performance is obtained by external large-scale assessments whose scores may be ranked between below basic $(<250)$, basic $(250$ to $<300)$, adequate $(300$ to $<375)$ and advanced $(\geq 375)$, and released through a specific form for each school on the site of the Board of Education of the state of São Paulo. It's interesting to mention that this research used the scores related to the discipline of Portuguese from students attending the 3 rd year of high school (since most of our sample was teaching in high school) presented on the 2011 report cards, to verify the validity of the criterion of the scales presented here. It was decided to use the report cards from 2011, because this was the closest disclosed index to the period of time in which the data in this research was collected.

\section{Data Collection Procedures}

This research started after authorization from the Research Ethics Committee (procedure CAAE
0777.0.146.000-10) and the Education Boards of the locations where the research would be conducted. As selection criterion, was considered the facility of researchers to have access to the schools, as well as the existence of Elementary School (final grades) and High School. Telephone contacts were established in 33 schools, from which only 17 accepted to take part in the research. In all participant schools a meeting with the Principal (or vice-principal) was conducted with the aim to explain the objective of the research, as well as to establish dates and schedules in which the data collection would be made. The data collections were conducted during the meetings in the classroom of the Collective Pedagogical Work Class, which the teachers and school coordinators attended, always with the presence of a researcher. The principals and or viceprincipals responded to the scales in their offices, in the presence of researchers, except for the principals of two schools, who responded during the meetings of the Collective Pedagogical Work Class.

\section{Semantic-Cultural Adaptation Procedures}

The process of semantic-cultural adaptation of the scales began after authorization of the authors of the original instruments. Special attention was given to the translation of instruments in order to ensure similar sense and meaning between the Brazilian version in Portuguese and the original versions in English. Adaptations were also conducted to the response scales, changing from the original 9 points, to 10 points in the adapted version, in order to obtain response scales following the guidelines by Bandura (2006). Specifically in relation to the scale of School Collective Efficacy Beliefs, we changed the word 'teacher' for the expression 'adults that work in this school', as we intended to apply the versions adapted to teachers and school managers. This decision was due to the delimitation dominion, which made necessary to identify the collective efficacy belief according to the perception of members that make up the school community.

Translated versions were submitted to the analyses of five judges who were familiar with the Social Cognitive Theory and who mastered both the English and Portuguese languages. The judges had knowledge about the educational dynamics for the work of high school teachers and training in posgraduate level. After analyses by the judges, minor adjustments were made in the texts, in order to complete the first version of each scale. These versions were subjected to the procedure of back-translation, in which a native English speaker, 
with knowledge of the Portuguese language, translated the adapted version of each scale from Portuguese into English. The back-translation demonstrated that the adaption to Portuguese was well done, as only little differences were found, such as: quanto, used in the Portuguese version to translate 'how much', was retranslated as 'how well'; 'are capable', used in Portuguese to translate 'can', was retranslated to 'are able'. In the texts in English, Bandura (1997, 2006, 2007) points out that the measurement of the efficacy belief should be relative to the perceived capability, and not to the ability. When translating this instrument, it was necessary to pay attention to this aspect, following the guidelines by Polydoro et al. (2010), so that the expression 'were capable' seems appropriate to give the perception of school collective efficacy.

As a next step in this process of adaptation, a pilot study with these scales was conducted. Voluntary collaboration of five teachers (who answered the two scales reviewed) and of four managers of basic education (who responded only to the school collective efficacy scale), who worked in different schools, was granted. These educators responded to the scales after registered consent and expressed their opinions about the clarity of the guidelines, of the items, and about the suitability of the content of the items to school reality, registering them in a space provided at the end of each scale. Through the information obtained via pilot study, the anchor words were changed to: not at all capable (values 1 or 2), somewhat capable (values 3 or 4), barely capable (values 5 or 6 ), capable (values 7 or 8 ) and very capable (values 9 or 10). The pilot study enabled to verify that the scales proved to be understandable regarding instructions and response options. However, some items have undergone minor modifications, such as the item that questioned about self-efficacy to develop good questions for the students. After being ranked in the pilot study as subjective, it became more explicit, questioning about the capability to ask good questions in tests and written activities. Two participants indicated the need to include more items on the scales, in order to address the teachers daily life more broadly, including aspects related to school management, the relation with the community, the physical conditions, and the external assessments. Although relevant these suggestions were not performed, in order to keep the original structure of the scale here adapted. After the pilot study, these scales were applied in a larger sample, to study for the search of evidence of validity, the object of this research.

\section{Procedures for Data Analysis}

Statistical Analysis System - SAS - version 9.2 was used to perform the data analysis. The data was checked by analyzing the results obtained via descriptive frequency, where atypical values were searched for. $20 \%$ of data was randomly checked. The adequacy of the sample was checked by Kaiser's MSA. The correlation between the items of the scales was verified by Pearson's correlation test. To verify the factorial structure, the data were analyzed using the exploratory factor, with Varimax rotation and, subsequently with Promax rotation. Cronbach's alpha was used to verify the internal consistency of the obtained factors and the scale as a whole. Spearman's correlation analysis was used to verify the relations between teacher self-efficacy and collective efficacy, in order to carry out the search for evidence of convergent validity. To verify the evidence of criterion validity, correlation analysis was also conducted using the Spearman test, with the variable 'performance index criterion', which has been implicated in theory and related to teacher self-efficacy and the school collective efficacy (Hoy, 2012). The non-parametric Spearman correlation test was perform because, by means of the Shapiro-Wilk, a significant deviation from the normality $(p<0.05)$ was identified.

\section{Results}

First presented are the results for each scale. Then, the results for the convergent and discriminant validity.

\section{Teacher Self-Efficacy Scale}

It was verified a Kaiser's MSA of 0.90 , indicating that the sample is adequate for the performance of factor analysis. Through descriptive analysis, it was found that the items presented means between $6.83(S D=1.80$, minimum 1 and maximum 10) and $8.39(S D=1.17$, minimum 3.00 and maximum 10.00). The items that compose this scale present positive correlations, significant (all $p<0.0001$ ), with coefficients ranked as weak $(r=0.29)$ and strong $(r=0.71)$ (Dancey \& Reidy, 2006).

It was used exploratory factor analysis, using the selection criteria factors with eigenvalues grater than 1 and Varimax rotation, to know how the items would organize the adapted version. Two factors were obtained, which explained $62.1 \%$ of variability of data, and demonstrated internal consistency of $\alpha=0.88$ for factor 1 and of $\alpha=0.86$ for factor 2 . As it can be seen, 
the psychometric indices and the contents of the factors indicated that the organization in two factors was adequate for this scale. However, since the modified scale was used in many cultures keeping the factory organization identical to the original, we decided to perform a new factory analysis, but, now, determining the organization in three factors.

Through Varimax rotation, the new analysis structured with three factors showed greater possibility to explain the variability of the data $(69.5 \%)$. Each factor consisted of four items, with loads higher than 0.40 . Item 8 and item 12 presented loads higher than 0.40 in two factors, but were allocated in the factor in which they presented the higher load, maintaining an organization equivalent to that shown in the original scale. Next, was performed the analysis by Promax rotation, which confirmed the organization in three factors with loads greater than 0.40 and indicated positive and moderate correlation between the three factors (correlation between factor 1 and factor $2=0.46$; factor 1 and factor $3=0.47$; and factor 2 and factor $3=0.54$ ). By Promax oblique rotation, only item 8 presented load greater than 0.40 in two factors, which was allocated in the factor that demonstrated higher load. Table $1 \mathrm{dem}-$ onstrates these reports.

Internal consistency analysis showed high reliability of the adapted scale both for the three factors ( $\alpha=0.85, \alpha=0.85$, and $\alpha=0.82$, respectively), and for the total of the scale $(\alpha=0.91)$. With the presented results, it was possible to verify that the scale adapted here confirmed the structure of the original scale, showing as an adequate instrument to measure teacher self-efficacy.

\section{School Collective Belief Scale}

The sample used in this analysis seems to be appropriate for carrying out the exploratory factor analysis, as indicated by the Kaiser's MSA measure (0.94). By means of the descriptive analysis, the items demonstrated means between $6.86(S D=1.66$, minimum 6.00 and maximum of 10.00$)$ and $7.58(S D=1.36$, minimum of 1 and maximum of 10.00). The items that compose this scale presented positive, significant correlations (all $p<0.0001$ ), with coefficients classified between moderate $(r=0.48)$ and strong $(r=0.84)$ (Dancey \& Reidy, 2006). By means of the selection criterion of factors greater than 1, was conducted exploratory factor analysis, with Varimax orthogonal rotation. The factor explained $65.6 \%$ of the variability. After analysis of the Scree plot, and choosing to extract two factors, $72.6 \%$ of variance was explained. This organization can be verified in Table 2.

The organization in two factors found in Table 2 is almost equal to the scale of the structure in its original version. Items $3,4,9$, and 11 exchanged factors in the adapted version. The organization set out in Table 2 was confirmed by a subsequent factor analysis, performed by Promax oblique rotation. Moderate positive correlation was found between the two factors $(r=0.66)$. Despite the exchange of four items, it was decided to keep the organization with two factors, since it was understood that the shift did not prevent conceptual unity in the two factors found in the adapted version. In the adapted version, factor 1 included all items that referred to the activities performed in the classroom and factor 2 was dedicated to the items that related to the activities that go beyond the classroom,

Table 1

Factorial Organization of the Teacher Self-Efficacy Scale - Short Version - Adapted

\begin{tabular}{|c|c|c|c|}
\hline Factor & Psychometric data & $\begin{array}{l}\text { Composed } \\
\text { of items }\end{array}$ & Example of item \\
\hline $\begin{array}{l}\text { 1. Efficacy in } \\
\text { instructional } \\
\text { strategies }\end{array}$ & $\begin{array}{l}\text { Explained variance: } 0.51 \% \\
\text { Factor loads } 0.72 \text { and } 0.81 \\
\text { Cronbach's } \alpha=0.85\end{array}$ & $9,10,12,6$ & $\begin{array}{l}\text { How well can you implement } \\
\text { alternative teaching strategies in } \\
\text { your classroom? }\end{array}$ \\
\hline $\begin{array}{l}\text { 2. Efficacy } \\
\text { in classroom } \\
\text { management }\end{array}$ & $\begin{array}{l}\text { Explained variance: } 0.62 \% \\
\text { Factor loadings between } 0.61 \text { and } 0.81 \\
\text { Cronbach's } \alpha=0.85\end{array}$ & $4,1,7,8$ & $\begin{array}{l}\text { How much can you do to control } \\
\text { disruptive behavior in the } \\
\text { classroom? }\end{array}$ \\
\hline $\begin{array}{l}\text { 3. Efficacy in student } \\
\text { engagement }\end{array}$ & $\begin{array}{l}\text { Explained variance: } 0.69 \% \\
\text { Factor loadings between } 0.63 \text { and } 0.80 \\
\text { Cronbach's } \alpha=0.82\end{array}$ & $3,2,5,11$ & $\begin{array}{l}\text { How much can you do to help your } \\
\text { students value learning? }\end{array}$ \\
\hline
\end{tabular}


Table 2

Information on the School Collective Efficacy Scale

\begin{tabular}{llll}
\hline Factor & $\begin{array}{l}\text { Composed by } \\
\text { items }\end{array}$ & Some psychometric data & Example of item \\
\hline $\begin{array}{l}\text { 1. Instrucional } \\
\text { strategies }\end{array}$ & $1,5,6,3,2,4$ & $\begin{array}{l}\text { Loads between } 0.64 \text { and } 0.84 \\
\text { Explained variance: } 65 \% \\
\text { Cronbach's } \alpha=0.93\end{array}$ & $\begin{array}{l}\text { How much can teachers in your school do } \\
\text { to produce meaningful student learning? }\end{array}$ \\
\hline $\begin{array}{l}\text { 2. Student's } \\
\text { discipline }\end{array}$ & $10,11,8,9,7,12$ & $\begin{array}{l}\text { Loads between } 0.50 \text { and } 0.94 \\
\text { Explained variance: } 7 \%\end{array}$ & $\begin{array}{l}\text { How well can adults in your school get } \\
\text { students to follow school rules? }\end{array}$ \\
\hline
\end{tabular}

though it requires a participation of all school agents for their stimulation.

In order to verify the reliability of this scale, internal consistency analysis was performed, which verified high consistency for both factors $(\alpha=0.93$ and $\alpha=$ 0.91 respectively) and also for the total of the scale $(\alpha$ $=0.95)$. The values for Cronbach's alpha suggest that this scale is reliable to measure the perceived collective teacher efficacy.

\section{Relations between Teacher Self-Efficacy, Collective Efficacy, and School Performance}

In this study, by means of Spearman correlation, moderate and positive correlation was verified between teacher self-efficacy and school collective efficacy $\left(\mathrm{r}_{\mathrm{s}}=\right.$ $0.51 ; p<0.0001 ; n=314)$, a result that shows convergent validity. Among the factors it was observed: (1) significant correlation of factor 1 of CE (Collective Efficacy) with factor 1 of TSE (Teacher Self-Efficacy) $\left(\mathrm{r}_{\mathrm{s}}=0.41 ; p<0.0001 ; n=314\right)$, with factor 2 of the TSE ( $\left.\mathrm{r}_{\mathrm{s}}=0.33 ; p<0.0001 ; n=314\right)$ and factor three 3 of TSE ( $\left.\mathrm{r}_{\mathrm{s}}=0.504 ; p<0.0001 ; n=314\right)$; and (2) significant correlation of factor 2 of $\mathrm{CE}$ with factor 1 of the TSE $\left(\mathrm{r}_{\mathrm{s}}=0.41 ; p<0.0001 ; n=314\right)$, with factor 2 of TSE $\left(\mathrm{r}_{\mathrm{s}}=0.38 ; p<0.0001 ; n=314\right)$, and with factor 3 of TSE ( $\left.\mathrm{r}_{\mathrm{s}}=0.51 ; p<0.0001 ; n=314\right)$.

To check the evidence of validity criterion of the scales analyzed here it was used the correlation between the variable 'performance index' and the constructs studied in this research. It was verified a weak positive correlation of the performance index with teacher selfefficacy $\left(\mathrm{r}_{\mathrm{s}}=0.12 ; p=0.034 ; n=303\right)$, with factor 1 $\left(\mathrm{r}_{\mathrm{s}}=0.15 ; \mathrm{p}=0.010 ; n=303\right)$ and with factor $3\left(\mathrm{r}_{\mathrm{s}}=\right.$ $0.13 ; p=0.027 ; n=303)$ of the teacher self-efficacy scale. There was no significant correlation of the performance index with factor $2\left(\mathrm{r}_{\mathrm{s}}=0.04 ; p=0.519 ; n=\right.$ 303), which is dedicated to analyze aspects related to the belief of teacher efficacy to deal with the discipline of students. It was also verified a weak and positive correlation of the performance index with the school collective efficacy $\left(r_{\mathrm{s}}=0.15 ; p=0.010 ; n=303\right)$, with factor $1\left(\mathrm{r}_{\mathrm{s}}=0,16 ; p=0,003 ; n=303\right)$ and with factor 2 $\left(r_{\mathrm{s}}=0.12 ; p=0.040 ; n=303\right)$ of this scale.

\section{Discussion}

As it can be observed, the two scales studied here showed adequate evidence of validity. Both presented items consistent with the contents and tasks that integrate the domains of efficacy beliefs and to which they are designed to, as commented by judges and observed in the pilot study. These items are written in a simple, direct way, in the present tense, being consistent with the recommendations on the formulations of items (Anastasi \& Urbina, 2000; Bandura, 2006; Polydoro et al., 2010).

Regarding the Teacher Self-Efficacy Scale - short version- it was possible to observe that it presented a possibility of explaining $69.5 \%$ of the variability of data and internal consistency of 0.91 . The factors efficacy on the instructional strategies (explained variance of $0.51 \% ; \alpha=0.85$ ), efficacy on classroom management (explained variance of $0.62 \% ; \alpha=0.85$ ), and efficacy on student engagement (explained variance of $0.69 \%$; $\alpha=0.82$ ) were composed of four items each, indicating that the scale replicated the same factor organization that has been presented in many cultures. This result contributes to confirm the factor structure and the high internal consistency of this scale previously identified in Western and Eastern cultures, as verified by Klassen et al. (2009), highlighting it as an appropriate scale for measuring teacher self-efficacy.

However, the result found in this study differed from the verified in the Brazilian adaption of the 
teacher self-efficacy scale - long version - (Polydoro et al., 2010). It is worth mentioning that the adaption of the long version of this scale considered in its primary studies only physical education teachers, aspect that may have affected the factorial organization found by Polydoro et al (2010).

The school collective efficacy, in turn, showed good psychometric data, such as possibility to explain $72 \%$ of explained variance and high internal consistency $(\alpha=0.95)$. These results help to confirm the viability of using this scale in different cultures, as demonstrated by Klassen et al. (2010). The two factors were organized in ways similar to the original (Tschannen-Moran \& Barr, 2004), whose identities were kept. This organization into two factors may contribute to develop the understanding of the measured construct and facilitate the development of intervention actions (Bandura, 2006). Such bifactorial structure differs from the obtained on the Brazilian Inventory of Teacher Collective Efficacy - IBECP - (Bzuneck et al., 2014), which, despite having more items, showed a unifactorial organization.

The significant and positive correlation between teacher self-efficacy and school collective efficacy presented indicated evidence of convergent validity for the scales studied here. This relationship has been extensively analyzed in the literature on the investigation of these constructs (Guerreiro-Casanova, 2013; Klassen et al., 2011). The significant and positive correlation between efficacy beliefs and the performance index verified signals evidence of criterion validity for the two scales analyses here. This statement is consistent with several studies that point to the correlation of these beliefs with the development of the students (Bandura, 1993; Guerreiro-Casanova, 2013; Hoy, 2012; Klassen et al., 2011). The results of this study seem to suggest that the scales analyzed here are formed as appropriate instruments for measuring perceived teacher self-efficacy and collective efficacy also in the context of the state of São Paulo.

It is of note that the results reported here demonstrate evidence of validity for the scores obtained on this research (Urbina, 2007), related to a sample of professors of the public sector in the state of São Paulo. Although the sample size allows approximately 25 respondents per item, an aspect that is considered adequate for the processes of search for evidence, it was recognized that the sample used here is a limitation of this study, as it may be little representative when considered the diversity of contexts within Brazil. Another limitation of this study concerns the criterion validity, which considered as performance index the grade obtained in Portuguese at SARESP by the students from the teachers who integrated the sample. This way of analysis was chosen, as it was similar to those already used in previous studies (Klassen et al., 2011; Tschannen-Moran \& Barr, 2004), but the use of performance indices obtained via large-scale assessments should be considered with caution (Guerreiro-Casanova, 2013).

Further studies are therefore, necessary, in the search for evidence that may broaden the information on the possibility of these scales to obtain valid scores in other samples of the Brazilian educational context. Also suggested is the possibility of analyzing the relations between the information obtained via these scales and the performance of students and teachers by qualitative means and/or more specific to the given sample. Specifically with regard to the school collective efficacy scale, it would be interesting to conduct new studies, in which the scores obtained by this scale could be compared to those obtained via the recently published Brazilian Inventory of Collective Teacher Efficacy IBECP (Bzuneck et al., 2014).

It is important to consider that these scales, which are instruments of self-report, portray the way individuals perceive themselves and how they perceive others. They capture the perceptions of the subjects in the construct being evaluated, but do not attest a factual information (Anastasi \& Urbina, 2000; Freire \& Almeida, 2001). Consistent with the theoretical concept underlying the self-efficacy and the collective efficacy constructs, it emphasizes that these beliefs are dynamic and vary depending on how one interprets the information coming from a field of study, among other sources of information (Bandura, 1997). In this sense, the use of scalar measures to modulate the planning of interventions must be used with caution. The interpretation of measures of efficacy beliefs should consider the circumstances on which they were obtained (Santos, 2011; Tschannen-Moran \& Johson, 2011).

\section{References}

Anastasi, A., \& Urbina, S. (2000). Testagem psicológica. Porto Alegre: Artes Médicas.

Azzi, R. G., \& Polydoro, S. A. J. (2010). O papel da autoeficácia e autorregulação no processo motivacional. In Boruchovitch, E., Bzuneck, J. A., \& Guimarães, 
M. S. E. R. (Eds..). Motivação para aprender: Aplicações no contexto educativo (pp. 126-144). Petrópolis: Vozes.

Bandura, A. (1993). Perceived self-efficacy in cognitive development and function. Educational psychologist, 28(2), 117-148. Retrieved from http:// jamiesmithportfolio.com/EDTE800/wp-content/PrimarySources/Bandura5.pdf

Bandura, A. (1997). Self-efficacy: The exercise of control. New York: W. H. Freeman.

Bandura, A. (2006). Guide for constructing self-efficacy scales. In F. Pajares \& T. Urdan. Self-efficacy beliefs go adolescents (pp. 307-337). USA Greenwich, CT: Information Age Publishing.

Bandura, A. (2008). O exercício da agência humana pela eficácia coletiva. In A. Bandura, R. G. Azzi \& S. Polydoro (Eds.). Teoria social cognitiva: Conceitos básicos (pp. 115-122). Porto Alegre: Artmed.

Bzuneck, J. A., \& Guimarães, S. R. (2003). Crenças de eficácia de professores: Validação de escala de Woolfolk e Hoy. Psico-USF, 8, 137-143. Retrieved from http://www.scielo.br/pdf/pusf/v8n2/ v8n2a05.pdf

Bzuneck, J. A., Boruchovitch, E., \& Guimarães, S. R. (2014). Eficácia Coletiva de Professores: Evidências de validade de construto de um questionário. Avaliaçãopsicológica, 13(3), 427-438. Retrieved from http:/ / pepsic.bvsalud.org/scielo.php?script $=$ sci_arttext\& pid $=$ S1677-04712014000300015

Dancey, C. P., \& Reidy, J. (2006). Estatística sem matemática para psicologia: Usando SPSS para windows. Porto Alegre: Artmed.

Dantas, M. A., Guerreiro-Casanova, D. C., \& Azzi, R. G. (2012). Eficácia coletiva de professores: Análise de escalas internacionais de avaliação. Avaliação psicológica,11(2), 181-190. Retrieved from http:/ / pepsic.bvsalud.org/scielo.php?pid=S1677-04712012000200004\&script=sci_arttext

Freire, T., \& Almeida, L. S. (2001). Escalas de avaliação: Construção e validação. In E. M. Fernandes \& L. S Almeida (Ed.). Métodos e técnicas de avaliação: Contributos para a prática e investigação psicológicas (pp. 109-128). Braga: Centro de Estudos em Educação e Psicologia - Universidade do Minho.

Goddard, R. D., Hoy, K. W., \& Hoy, A. W. (2004). Collective efficacy beliefs: Theoritical developments, empirical evidence, and future directions. Educational researcher, 33(3), 3-13. doi: 10.3102/0013189X033003003

Guerreiro-Casanova, D. C. (2013). Crenças de eficácia de gestores escolares e de docentes no ensino médio paulista. 177p (Tese de doutorado), Faculdade de Educação, Universidade Estadual de Campinas - Campinas.

Hoy, W. (2012). School characteristics that make a difference for the achievement of all students: A 40-year odyssey. Journal of educational administration, 50(1), 76-97. DOI: 10.1108/09578231211196078

Klassen, R. M., Bong, M., Usher, E. L., Chong, W. H., Huan, V. S., Wong, I. Y. F., \& Georgiou, T. (2009). Exploring the validity of a teachers' self-efficacy scale in five countries. Contemporany educational psychology, 34, 67-76. doi:10.1016/j.cedpsych.2008.08.001

Klassen, R. M., Usher, E. L., \& Bong, M. (2010). Teachers collective efficacy, job satisfaction, and job stress in cross-cultural context. Journal of experimental education, 78, 464-486. doi: 10.1080/00220970903292975

Klassen, R. M., Tze, V. M. C., Betts, S. M., \& Gordon, K. A. (2011). Teacher efficacy Research 19982009: Signs of progress or unfulfilled promise? Educational psychology review, 23, 21-43. doi 10.1007/ s10648-010-9141-8

Polydoro, S. A. J., Winterstein, P., Azzi, R. G., Carmo, A. P., \& Venditti Junior, R. (2004). Escala de autoeficácia do professor de educação física. Avaliação psicológica: Formas e contextos (p. 330-337). Braga: Psiquilíbrios edições.

Polydoro, S. A. J., Azzi, R. G., \& Vieira, D. (2010). Orientações de construção e aplicações de escalas na avaliação de crenças de autoeficácia. In A. A. A. Santos, E. Boruchovith, E. Nascimento \& F. F Sisto (Ed.). Perspectivas em avaliação psicológica (pp.189-210). São Paulo: Casa do Psicólogo.

Santos, A. A. A. (2011). O possível e o necessário no processo de avaliação psicológica. In Conselho $\mathrm{Fe}$ deral de Psicologia. Ano da avaliação psicológica - Textos geradores (pp. 13-16). Brasilia: Conselho Federal de Psicologia.

Skaalvik, E. M., \& Skaalvik, S. (2007). Dimensions of teacher self-efficacy and relations with strain factors, perceived collective teacher efficacy and teacher burnout. Journal of educational psychology, 99(3), 611-625. Retrieved from 
http: / / psycnet.apa.org/index.cfm?fa=buy. optionToBuy\&id=2007-11761-012

Tschannen-Moran, M., Woolfolk-Hoy, A., \& Hoy, W. K. (1998). Teacher efficacy: Its meaning and measure. Review of educational research, 68, 202-248. Retrieved from http://mxtsch.people.wm.edu/Scholarship/ RER_TeacherEfficacy.pdf

Tschannen-Moran, M., \& Woolfolk-Hoy, A. (2001). Teacher efficacy: Capturing and elusive construct. Teaching and teacher education, 17, 783-805. doi:10.1016/S0742-051X(01)00036-1

Tschannen-Moran, M., \& Barr, M. (2004). Fostering student learning: The relationship of collective teacher efficacy and student achievement. Leadership and policy in schools, 3(3), 187-206. doi: 10.1080/15700760490503706
Tschannen-Moran, M., \& Johson, D. (2011). Exploring literacy teachers self-efficacy beliefs: Potential sources at play. Teaching and teacher education: An international journal of research and studies, 27(4), 751761. doi:10.1016/j.tate.2010.12.005

Urbina, S. (2007). Fundamentos da testagem psicológica. Porto Alegre: Artmed.

Woolfolk, A. E., \& Hoy, W. K. (1990). Prospective teachers' sense of efficacy and beliefs about control. Journal of educational psychology, 82, 81-91. Retrieved from http://psycnet.apa.org/index.cfm?fa=buy. optionToBuy\&id=1990-20992-001

Recebido: 27/11/2014

Primeira reformulação: 10/02/2015

Aprovado: 27/02/2015

Nota das autoras:

A primeira autora agradece o apoio da Fundação de Amparo à Pesquisa do Estado de São Paulo - FAPESP - (Processo $\left.\mathrm{n}^{\mathrm{o}} 2010 / 51657-1\right)$.

Sobre as autoras:

Daniela C. Guerreiro Casanova é pedagoga, mestre e doutora em Educação pela Universidade Estadual de Campinas. Atualmente, atua como pesquisadora pós-doutorado na Universidade Nove de Julho e investiga aspectos relacionados às crenças de eficácia de gestores, professores e estudantes.

E-mail: danielaguerreiro@yahoo.com.br

Roberta Gurgel Azzi é professora livre docente junto ao Departamento de Psicologia Educacional da Faculdade de Educação da Universidade Estadual de Campinas. Estuda, investiga e orienta trabalhos no referencial da Teoria Social Cognitiva.

E-mail: betazzi@uol.com.br

Contato com as autoras:

Profa. Dra. Roberta Azzi

E-mail: betazzi@uol.com.br

Departamento de Psicologia Educacional, Faculdade de Educação, Universidade Estadual de Campinas Av. Bertrand Russel, 801, Cidade Universitária Zeferino Vaz, Campinas/SP

CEP: $13083-865$ 
